\title{
CAMBRIDGE UNIVERSITY NATURAL RADIOCARBON MEASUREMENTS IV NUCLEAR-WEAPON TESTING AND THE ATMOSPHERIC RADIOCARBON CONCENTRATION
}

\author{
H. GODWIN and E. H. WILLIS \\ Cambridge University
}

\section{A. Annual Rings of Populus nigra, 1953-1959}

In continuance of investigations upon successive annual crops of oats reported in Radiocarbon Supplement, Volume 2, we undertook the analysis of successive annual rings of a tree that had been growing throughout the period covered by the oat-crop assays, namely 1953 to 1959. The selected tree was a straight-boled specimen of Populus nigra from the Forestry Commission's plantations at Santon Downham, near Thetford, Norfolk. It had been planted in 1929 and was felled on 21 October, 1959. Shortly afterwards, it was brought into the laboratory and sawn into slices just over $1 \mathrm{in}$. thick. The surfaces having been smoothed, the annual-ring contacts were marked, and within each annual ring the inner (spring) wood was marked off from the outer (autumn) wood. The tree had been chosen as one exhibiting rapid growth and it proved fairly easy to dissect off with a chisel all the separate half-rings between spring 1953 and the end of 1959. In the event, activities were determined only upon four of the half or whole rings.

Since it was thought possible that some of the abundant starch present in the wood might have been directly translocated from the stored starch deposits of earlier years, in two instances starch was removed from the ring samples by acid hydrolysis before combustion and assay.

All activities are quoted as a percentage variation from the activity of the 100-yr-old oak standard. It must be remembered that the Suess effect accounts for a negative variation of about $-3.3 \%$ between the standard and the 1953 samples, whilst the age correction is $+1.2 \%$, leaving a negative balance of about $2 \%$.

$\begin{array}{lllr}\text { Q-453 } & 1953 & \text { Whole ring } & -2.2 \%+0.7 \% \\ \text { Q-454 } & 1953 & \text { Whole ring-destarched } & -2.9 \%+0.7 \% \\ \text { Q-446 } & 1958 & \text { Autumn half-ring destarched } & +13.8 \% \pm 1.0 \% \\ \text { Q-447 } & 1958 & \text { Spring half-ring } & +14.5 \% \pm 1.0 \% \\ \text { Q-443 } & 1959 & \text { Whole ring } & +25.2 \% \pm 1.3 \% \\ \text { Q-444 } & 1959 & \text { Whole ring-destarched } & +23.1 \% \pm 1.3 \%\end{array}$

Increase in activity of about $27 \%$ between wood grown in 1953 and that grown in 1959 is comparable with the increase of $32 \%$ in the activity of oat grains grown in these respective seasons.

In the two assays for autumn and spring wood of 1958, there is no evidence that the spring wood of one season might have been largely built from carbohydrate synthesized in the previous season, stored over the winter and mobilized in the spring. 
Likewise, in the 1959 analyses there is no evidence that starch from an earlier season and with a different radiocarbon activity is present, stored in the wood of a given year.

In this tree it would appear that the year's growth of wood is largely the product of photosynthesis in that year: this does not, of course, exclude the possibility that it might be otherwise with other species or other conditions of growth.

\section{B. Tropospheric Radiocarbon Activity in 1960)}

Measurements made upon the tropospheric radiocarbon activity since large scale nuclear weapon testing began, have all indicated a seasonal variation in concentration which reaches a peak level for any particular year in the early summer in the Northern Hemisphere (Münnich and Vogel, 1958). This is also characteristic of other fission products, particularly strontium 90 . caesium 137, zirconium 95 and tungsten 185 (Pierson et al., 1960). The seasonal peak was much in evidence in 1959, the first year after the moratorium on testing, when a large accumulation in the autumn of 1958 flushed into the northern hemisphere troposphere the following spring (Willis, 1960; Tauber, 1960 ; Broecker, 1960). It was of great importance to see whether this observation would be repeated in the 1960 season, for it would provide a valuable guide to mean residence and turnover times of the phases of the atmosphere.

A site to windward of the city of Cambridge, free from possible fuelcarbon contamination, was chosen for the collection of the samples. They were of two kinds, organic and inorganic. The organic samples were successive crops of mustard (Sinapis alba), grown from seed at regular intervals. The final dry weight after three weeks was greatly in excess of that of the seed, and no correction has been applied for initial carbon content of the seed. A sample of oats grown in a field nearby was also assayed, and the result was in general agreement with that given by the mustard plants. The inorganic sample was obtained as carbonate by exposing to the air 2 litres of $\mathrm{N}$. sodium hydroxide for 3 or 4 days, usually during the last few days of growth of the mustard plants. Carbonate yields tended to vary around $60 \%$, and $\mathrm{C}^{12} / \mathrm{C}^{13}$ ratios in the precipitate might therefore be expected also to vary slightly from sample to sample. In the absence of mass-spectrometric facilities, Broecker's average $C^{13}$ value of $-21 \%$, which had been observed for samples taken under comparable conditions, was taken as the correction to the $\mathrm{C}^{14}$ value. In the case of the organic material, $\mathrm{C}^{13}$ was taken as -25 , again an average of Broecker's measurements. One atmospheric sample from Gilleleje, Denmark $156^{\circ} 7^{\prime} \mathrm{N}$ Lat. $12^{\circ} 19^{\prime} \mathrm{E}$ Long), collected by Tauber in June and July as part of a similar investigation, was measured and found to give close agreement with the British measurements.

The season's results appear to indicate that there has been no significant peak in the 1960 level of activity. In 1959, a concentration gradient existed between the northern and southern hemispheres, varying from $\mathrm{C}^{14}$ of about 310 in the $\mathrm{N}$ to about 180 in the $\mathrm{S}$. In 1960 there are indications that the tropospheres of both hemispheres are approaching equilibrium at around 220. The question arises as to the fate of the inflow of radiocarbon from the northern 
hemisphere stratosphere to the troposphere. The absence of any seasonal peak might indicate that the inflow was equal to the outflow down the concentration gradient to the southern hemisphere and into the oceans. Alternatively, it could mean that there has been little or no inflow of radiocarbon from the stratosphere this year. If the amount being taken up by the oceans is large, then this will be soon indicated by the decay time of the tropospheric activity which will provide an indication of the troposphere and surface ocean turnover rate.

\begin{tabular}{|c|c|c|c|c|}
\hline \multicolumn{5}{|c|}{ Organic series, 1960} \\
\hline \multirow[b]{2}{*}{ Q No. } & & & $\begin{array}{l}\text { Estimated } \\
\qquad \mathrm{C}^{13}\end{array}$ & \\
\hline & March $10-30$ & $\begin{array}{c}8 \mathrm{C}^{14} \\
209\end{array}$ & $\begin{array}{l}\delta \mathrm{C}^{13} \\
-25\end{array}$ & $\begin{array}{c}\left(\Delta C^{14}\right) \\
212 \pm 9\end{array}$ \\
\hline $\begin{array}{l}500 \\
501\end{array}$ & $\begin{array}{l}\text { March } 10-30 \\
\text { April } 1-21\end{array}$ & $\begin{array}{l}202 \\
175\end{array}$ & -25 & $184 \pm 9$ \\
\hline $\begin{array}{l}501 \\
502\end{array}$ & $\begin{array}{l}\text { April 1-21 } \\
\text { April 22-May } 12\end{array}$ & $\begin{array}{l}175 \\
185\end{array}$ & -25 & $194 \pm 9$ \\
\hline 511 & Oats picked July 24 & 187 & -25 & $196 \pm 9$ \\
\hline \multicolumn{5}{|c|}{ Carbonate series, 1960} \\
\hline 504 & May $16 \cdot 19$ & 213 & -21 & $213 \pm 9$ \\
\hline 505 & May 31-June 3 & 205 & -21 & $205 \pm 9$ \\
\hline 506 & June $21-27$ & 218 & -21 & $218 \pm 9$ \\
\hline 508 & July $15-18$ & 209 & -21 & $209 \pm 9$ \\
\hline 513 & Aug. 4-8 & 235 & -21 & $235 \pm 9$ \\
\hline 515 & Aug. 29-Sept. 1 & 202 & -21 & $202 \pm 9$ \\
\hline 524 & Oct. 1-Oct. 7 & 216 & -21 & $216 \pm 9$ \\
\hline 523 & Nov. $10-13$ & 181 & -21 & $181 \pm 9$ \\
\hline $520 /$ & $\begin{array}{l}521 \text { June-July Gillelej } \\
\text { Denmark }\end{array}$ & 12 & -21 & $212 \pm 9$ \\
\hline
\end{tabular}

\section{Other bomb-affected carbon samples}

$\begin{array}{crrc} & \delta \mathrm{C}^{14} & \delta \mathrm{C}^{13} & \Delta \mathrm{C}^{14} \\ \text { Q-471. Human testes } & 149 & -25 & 158 \pm 20\end{array}$

Submitted by the Medical Research Council, Radiobiological Research Unit, Harwell, England (J. F. Loutit), and obtained from a young healthy person, the victim of a road accident. The $\Delta \mathrm{C}^{14}$ value represents the concentration of bomb-derived carbon in healthy genetical tissue in early 1960. The dry weight of the sample was small, and the result was obtained by a dilution technique.

\begin{tabular}{|c|c|c|c|}
\hline & $\delta \mathrm{C}^{14}$ & $\delta \mathrm{C}^{13}$ & $\Delta \mathrm{C}^{14}$ \\
\hline $\begin{array}{l}\text { Q-472. Horse hair } \\
\text { Clipped September } 1959 .\end{array}$ & 148 & -25 & $156 \pm 8$ \\
\hline
\end{tabular}

REFERENCES

Anderson, W., Bentley, R. E., Burton, L. K., Crookall, J. O., and Greatorex, C. A., 1960 , Radioactive fallout during 1959: Nature, v. 186, p. 925-928. Barclay, F. R., Elliot, M. J. W., Goldsmith, P., Jelly, J. V., and Osborne, A. R., 1960, Some 
preliminary measurements of the tritium and carbon 14 content of the stratosphere over England: A. E. R. E. Report, R. 3271 (U. K.), p. 1-9.

Bien, E. S., and Suess, M. E., 1959, Increase of $\mathrm{C}^{14}$ in the atmosphere from artificial sources measured in a Californian tree: Zeitschr. für Physik, v. 154, p. 172-174.

Broecker, W. S., and Olson, E. A., 1960, Radiocarbon from nuclear tests II: Science, v. 132, p. 712-721.

Broecker, W. S., and Walton, A., 1959, Radiocarbon from nuclear tests: Science, v. 130 p. $309-310$.

Feeley, H. W., and Spar, J., 1960, Tungsten-185 from nuclear bomb tests as a tracer for stratospheric meteorology: Nature, v. 188 , p. 1062-1064.

Münnich, K. O., and Vogel, J. C., 1958, Durch atomexplosionen ergeugter Radiokohlenstoff in der Atmosphëre: Naturwissenschaften, v. 14, p. 327-329.

Peirson, D. H., Crooks, R. N., and Fisher, E. M. R., 1960, Radioactivity of the atmosphere due to distant nuclear test explosions: Nature, v. 186, p. 224-225.

Tauber, H., 1959, Post bomb rise in radiocarbon activity in Denmark: Science, v. 131, p. $921-922$

to the 1960, Latitudinal effect in the transport of radiocarbon from the stratosphere to the troposhere: Proc. I.A.E.A. Conf. (Copenhagen 1960) on the Use of Radioisotopes in the Physical Sciences and Industry, $10 \mathrm{p}$. (preprint)

Willis, E. H., 1960, Atmospheric radiocarbon activity in 1959: Nature, v. 185, p. 552-553. 